Article

\title{
The Structure of the Start-Up Business Model-Qualitative Analysis
}

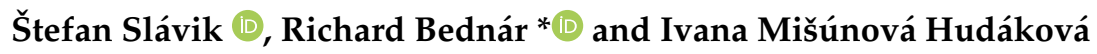 \\ Department of Management, Faculty of Business Management, University of Economics in Bratislava, \\ 85235 Bratislava, Slovakia; stefan.slavik@euba.sk (Š.S.); ivana.misunova@euba.sk (I.M.H.) \\ * Correspondence: richard.bednar@euba.sk; Tel.: +421-903-967-097
}

Citation: Slávik, Š.; Bednár, R.;

Mišúnová Hudáková, I. The Structure of the Start-Up Business Model-Qualitative Analysis. Sustainability 2021, 13, 8386. https:// doi.org/10.3390/su13158386

Academic Editors: Jose Ramon Saura and JinHyo Joseph Yun

Received: 18 May 2021

Accepted: 22 July 2021

Published: 27 July 2021

Publisher's Note: MDPI stays neutral with regard to jurisdictional claims in published maps and institutional affiliations.

Copyright: (c) 2021 by the authors. Licensee MDPI, Basel, Switzerland. This article is an open access article distributed under the terms and conditions of the Creative Commons Attribution (CC BY) license (https:// creativecommons.org/licenses/by/ $4.0 /)$.

\begin{abstract}
The aim of the research is an in-depth and detailed knowledge of the start-up business model, which is structured according to Canvas visualization. The research sample contains 106 startups operating in Slovakia. Each start-up was researched by a member of the research team, who personally recorded the statements of the founder. The research results are based on qualitative analysis and synthesis of statements of the founders of start-ups. The main results of the research are a summary view of the business model of the examined start-ups, which expresses the peculiarities of the start-up business making, including priorities within its blocks, and the identification of space for variations in the business model of start-ups. A secondary result of the research is the subjective and objective circumstances of the creation of a business idea, its content, confirmation of its originality, and the peculiarity of the start-up development process. The practical use of the results consists in providing a pattern of the business model and the possibilities of its variation, which are the result of field research of real and functioning start-ups. The originality and value of the research lie in the direct collection of qualitative data, immediate knowledge of business reality, and the synthesis of results into a comprehensive and detailed picture of the start-up business model.
\end{abstract}

Keywords: start-up; business idea; business model; Canvas

\section{Introduction}

Start-up is a very small nascent enterprise that is expected to discover or create a new need, an attractive and unusual product, a scalable business model, and rapid significant growth. It creates new jobs, brings solutions to current problems in the economy, technology, ecology, communication, leisure, and entertainment. Start-up is a relatively new and attractive business form that is being explored in a broader economic and industry context [1]. However, there is only a small volume of knowledge about its internal structure. Its position in the business world is not negligible, so it is important to understand the essence of its work. When founding a start-up, the founders address several key questions: Who will be the customer? What would the customer need? What technology will be the basis of the business making? How do we build and develop an enterprise? How do we get financial resources? What will be the source of revenue? Answering these questions means building a business model. It consists of blocks that together create business performance, generate sales, and make a profit. Building a functioning business model is crucial for a start-up because it becomes a regular enterprise and can claim the favor of customers and investors. In-depth and detailed knowledge of the structure of the start-up business model, including the creation of a business idea and its development, will enable a better understanding of the conditions and processes of its operation and the fulfillment of its business purpose.

The main goal of the research is to clarify the structure of the start-up business model based on a qualitative analysis, because a non-functioning business model is one of the most common causes of start-up failure. The secondary goal of the research is the business 
idea because it is the primary reason for the creation of the business model and the business model is a tool for the implementation of the business idea. A secondary goal of the research is also the process of start-up development because this micro-enterprise is in a state of relatively rapid transformation, which has an impact on the characteristics of its business model. The research concept is therefore based on a qualitative analysis of the chain: business idea $\rightarrow$ start-up development $\rightarrow$ start-up business model. The research and studies carried out so far focused on start-ups as an entrepreneurial category group of companies and have not penetrated into their internal structure and development dynamics. This is the originality and novelty of the research carried out, which fills the gap between research that monitors the situation in the size category of companies and research that deals with the start-ups at the level of case studies [2,3]. New findings from the presented research should contribute to the thoughtful and purposeful establishment and development of start-ups, and thus support the viability and sustainability of this entrepreneurial form, because sustainable strategies are based on data [4].

The researched topic supports the economic and business aspects of sustainability [5]. Qualitative analysis of business models helps to reveal unsuspected possibilities of their improvement, reduce the range of causes of their failure, increase the probability of their survival, and thus strengthen the sustainability of this dynamic business form, which is an engine of innovation that also contributes to a new sustainability-oriented society. There is also an urgent need to better understand data-driven innovation strategies [6].

Business sustainability means continuously and constantly innovating all components of the business. The inspiration for the sustainability of a start-up business making is also the proposals from Kanwal and Awan [7], who compiled a multi-level conceptual framework for sustainable innovation (design thinking, biomimicry design, biophilic design, eco-philia thinking). Awan [8] then divides sustainable innovations into four categories (reflexive, integrative, connective, and structural innovation). Their business sense lies in the fact that they significantly affect the organizational value outcomes (value creation and value appropriation).

\section{Establishment and Development of Business}

Start-up is a newly created business project, which aimed to find or create an unsatisfied need, satisfy this need with appropriate benefits, and confirm its existence with a functioning business model. Start-up should discover new markets and create products with high added value [9]. It is a young enterprise under the age of ten [10] that must build a repeatable and scalable business model [11] with high demand potential [12]. The OECD defines start-ups as a of young businesses within the first three years of operation (0-3 years old) [13]. According to European Startup Network, a start-up is an independent, organisation, which is younger than five years and is aimed at creating, improving and expanding a scalable, innovative, technology-enabled product with high and rapid growth [14]. European Startup Monitor defines, that a start-up has to be younger than ten years. It has to have an innovative product and/or service and/or business model. The start-up has to aim to scale up (intention to grow the number of employees and/or turnover and/or markets in which they operate) [15]. In our research we lean towards this opinion.

The number of start-ups is constantly growing. Statistically, there are about 305 million total start-ups created in a year and 1.35 million businesses out of those start-ups are tech related. In addition, there are 3173 companies that increased from 185 accelerator programs [16].

Start-ups are drivers of change that bring innovation and find new solutions to old problems [17]. They are inventing new business models that surprise existing markets. Their business is based mainly on new technologies and knowledge [18]. Several studies indicate that start-ups have a positive impact on the economy and contribute to its development [19]. Successful start-ups create new jobs and contribute to economic prosperity [20]. 
The most common motive of start-up founders is the desire for self-realization [21]. A passion for a specific business also plays an important role [22]. They are also motivated by the desire for entrepreneurial independence [23], liberation from employee status, and the growth of personal wealth [24]. The motivation to get rich also proved stronger in a Kauffmann Foundation study that analyzed 549 start-ups [25]. These personal goals are then transformed into the strong commitment and high work commitment of the start-up founders [26].

Establishing a start-up is characterized by high uncertainty [27] and constant change. Understanding the initial processes and challenges is a key factor for success [28]. The key role is played by the personality of the founder [29], especially his proactive approach [30].

Building a business model is also accompanied by seeking funding for business development. Financial literacy is extremely important for start-ups [31]. At the establishment of a company, they faced limited access to finance, which is a major obstacle to rapid growth. In the beginning, they finance the company from their own savings or with the help of their surroundings [12]. They rely on personal resources, which are usually not enough [32]. Effective growth requires in particular external resources [33], which is difficult to obtain [34]. Start-ups with smaller initial assets are less likely to gain investment [35]. Finding external sources of funding has pitfalls that scientific research analyzes very little.

The process of creating and developing business ideas is full of trials and errors, which triggers a series of critical events and often leads to the demise of the company [36]. The founders defend the uniqueness of the idea and its value in front of customers and investors. Assessing the originality of an idea is difficult [37], but crucial because it is an important condition for business success [38]. The question is whether the founders can accurately and objectively determine the originality of their idea.

The business model shows the resources and processes that are a condition for the proper functioning of the company. A study by Zhang [39] identified six components of the business model: the consumer, the niche, the delivery, the revenue, the funding model, and the profit-sharing model. Afuah [40] shows a business model with the following key components: industry factors, resources, positions, costs, and activities, the interplay of which results in a profit. Osterwalder and Pigneur [41] divide the business model into a clear and comprehensive visualization with nine blocks: customer value proposition, customer segments, customer relationships, distribution channels, key resources, key activities, key partners, cost structure, and revenue streams. Research on business models can only become more impactful if it is aimed on the development of entrepreneurial taxonomies and conjecture formation [42].

The main problem of start-ups is to create a functioning and effective business model. A study by Iwu [43] showed that one of twelve start-ups fails within two to three years. CB Insights [44] analyzed 101 failed companies and concluded that the most important factor for success is a quality business model. Slávik and Hagarová [45] analyzed 76 start-ups and found that imperfection, incompleteness, or failure of the business model was one of the main reasons for the failure of start-ups. Fractel company analyzed the statements of 193 founders, which were collected between the years 2000 and 2016 [46]. Approximately $51 \%$ of the analyzed start-ups failed due to a non-functional business model.

Business model research usually focuses more on larger and more mature companies, but there is also a need to research very small companies/start-ups [47]. According to the authors, the peculiarity of creating a start-up business model lies in the constant change in the structure of the offered value and the model. When creating a model, founders often seek value and innovation only where it can be easily observed [48]. Their problem is that they transform their vision into false hypotheses of the business model, which they then test using a series of MVPs (minimum viable products) [49]. The correct compilation of the business model plays a key role here [50]. Start-ups could develop their models better by verifying managerial hypotheses [51].

Proper thinking about creating a start-up business model will determine the direction of the start-up for several years. This decision is often long-term and crucial for business 
success [52]. Nevertheless, there is not enough knowledge about how to properly build a start-up model. It is rather known from scientific studies which factors do not influence this construction [53]. It is still unclear what happens in start-ups during the development of the business model. Knowledge about business models of start-ups is little present in the academic literature [54]. Despite its popularity, the literature on this topic is superficial. There is a lack of structured and detailed analysis of models and integration of new knowledge [55]. The quality of business model helps achieve the sustainable management [56]. Deeper and more comprehensive penetration into the business model of a start-up and its context is not only of cognitive significance but can significantly contribute to the survival and maintenance of business and business success.

A customer-driven innovation strategy will become a viable way to enhance a business [57]. The process of business model innovation is not a linear process but a dynamic cycling process with open innovation dynamics [58]. Business Model Innovation is suitable for all types of companies, but young companies are more motivated to do radical changes and to try new and disruptive ways of attacking a market to find competitive advantages [59]. One of the ways on how to innovate a business model is to have open innovation, which lets firms find new breakthroughs [60,61].

Qualitative analysis is a tool relatively frequently used in start-up research, as data, knowledge and experience can be obtained from a small circle of respondents, most often the founder or manager of a start-up [62]. Semi-structured interviews (questionnaires) are mostly used for data collection, e.g., Ghezzi [63], Voinea [3], Tukiainen [64]. Interviews are complemented by case studies, e.g., Guthbrod [65], Linton [66]. If it is not possible to get personal contact with the start-up, then some researchers analyze the websites of start-ups, e.g., Hilbig et al. [67] and Tiba et al. [68]; even Kuckertz et al. [69] analyzed media reports on start-ups in the Nexis database.

There is a lack of research in creating a start-up business idea, verifying the originality, and building a start-up business model. Existing research often deals with start-ups only superficially, without in-depth analyses, and does not explain the interrelationships. Standard research is often created only based on a questionnaire, without personal meetings and individual examination of start-ups. This often results in quick reports, but without revealing internal processes in these unique environments of young companies. Therefore, researchers should focus more on a detailed and qualitative examination of start-upsthe emergence of an entrepreneurial idea, confirming the originality of the idea and the systematic building of the structure of the business model, because these topics are almost never examined.

\section{Goal and Methods of Research, Research Sample}

The purpose of the research is to deepen and broaden knowledge about how startuppers think about creating a business idea, how they look for business space (industry), how they verify the originality of their business ideas, and especially the structure of the start-up business model. Start-up is a small nascent company with very limited resources, whose business model is different from larger and older companies. The business model of a start-up has its own special features that fundamentally determine its existence and further development. The main goal of the research is to describe, analyze and explain the content and detailed structure of the start-up business model. The secondary goal of the research is to clarify the subjective and objective circumstances of the origin of a business idea, its content, its originality confirmation, and the peculiarities of the start-up development process.

The research sample included 187 enterprises originally but was reduced to 106 startups, as companies with incomplete data and companies whose nature did not correspond to the characteristics of the start-up were excluded. Studied start-ups were founded in 2014 and later, except for five start-ups based in the years 2012-2014. The average number of employees in surveyed start-ups is 9.3. Excluding the three start-ups employing more than 50 employees, the average number of employees was 7.12. Industry incorporation 
of researched start-ups according to SK NACE (Nomenclature statistique des économiés économiques dans la Communauté européenne):

A-Agriculture (forestry and fishing): 2

C-Industrial production: 22

G-Wholesale and retail trade: 10

I-Accommodation and food services: 3

J-Information and communication: 41

K-Financial and insurance activities: 1

M-Professional, scientific, and technical activities: 18

N-Administrative and support service activities: 1

P-Education: 4

$\mathrm{R}$-Arts, entertainment, and recreation: 1

S-Other activities: 3

The research sample was compiled according to the territorial criterion, because Slovakia is a small country (5.5 million inhabitants) and most of the important business, economic and cultural capacities are concentrated in the capital and its surroundings. Bratislava is a center of attraction not only for large companies, but it is also a central base for start-up businesses. Other selection criteria were the age of the start-up (five years or less) and the fulfillment of at least one business condition: new original technology, or significantly better use of existing technology, or discovery and satisfaction of a completely new need, or invention/creation and satisfaction of a completely new need, or satisfaction existing needs in a significantly better or cheaper way. The research did not prefer the industry representation of start-ups, because it followed the general structure of the researched objects (business idea, start-up development process, start-up business model).

Method-Field research took place in the period from September to November 2019 in the territory of Slovakia and start-ups are mainly based in the capital of Bratislava and its surroundings. The structure of research questions for examining business models used the Business Model Canvas method [41]. This model is sufficiently concise and complex and divides the business model into nine blocks (customer value proposition, customer segments, customer relationships, distribution channels, key resources, key activities, key partners, cost structure, revenue streams). Franceschelli, Santoro, and Candelo [70] also used the same instrument in their research. The results of the research are therefore based on a qualitative analysis of the respondents' statements and report on the choice of industry, the nature of the business idea, the causes of its origin, the degree of originality, and the specifics of individual parts of business models. Each start-up was examined by one member of the research team, who personally (face-to-face) recorded the evaluations and answers of the founder/owner in the questionnaire. Open questions were asked, and any ambiguities were immediately explained. Similar Swedish research on new technologybased firms was conducted through a research agency [2]. The questions were mostly with quantitative ranking scales, without the participation of original researchers and without the possibility of consultation and correction.

The questionnaire collected data about staffing of the start-up, date of establishment, composition of investments, characteristics of the business idea, development phase of the start-up (idea development and acquisition of investment), description of individual business model blocks and final summary evaluation/experiences (positive, negative, pivots). Most of the data obtained were used in the presented research.

The researchers tried to identify, describe, and characterize the reality, the attributes of the start-up, and its actions, which could not be quantified in the appropriate measurement units or the scoring scales. Researchers did not ask for opinions, impressions, or beliefs. The staffing of start-ups is very limited and the quality cooperation was limited to one person, and therefore the founder of the start-up, who knows the start-up comprehensively and cross-sectionally, was addressed. Confrontation of the founder's statements with the statements of his colleagues, who do not have a comprehensive overview of the start-up and the content of the research, does not make sense. The reliability of the statements is 
indirectly confirmed by the results of research, which do not seem exaggerated, do not result in excellent characteristics or exceptional business results of the analyzed start-ups, and therefore a high degree of congruence between reality and the founder's statements can be assumed.

Qualitative analysis is based on grouping answers around key statements. When analyzing the answers to the qualitative questions, the researchers identified key statements around which they recorded/clustered the same or very similar responses; the clustering corresponds to the identified reality and therefore may be quite extensive and diverse. The occurrence of each cluster of statements is recorded as a share (\%) in the total number of qualitative statements.

The research results are therefore based on qualitative analysis and synthesis of respondents' statements and report on the nature of the business idea, the causes of its origin, degree of originality, industry selection, start-up development, and detailed content of start-up business model blocks.

\section{Results}

\subsection{Creating a Business Idea}

Industry selection-finding a place to do business is mostly conditioned by observing an unmet need $(30.4 \%)$, or by the speech of entrepreneurs, the so-called holes in the market along with looking for a need or product abroad. Personal interest, passion, hobby, environmental responsibility, family background, and sympathy for a business play an important role in choosing a specific industry $(19.6 \%)$. The choice of business is significantly influenced by the knowledge of the industry from the position of a former employee who uses the acquired experience (13.4\%) and applies the acquired education and professionalism (11.6\%). Attractive and promising growth of the industry is the reason for the choice for $9.9 \%$ of entrepreneurs and the industry not demanding, e.g., on expertise and start-up capital is the reason for entry for $8.1 \%$ of entrepreneurs. The similarity, relatedness, or continuity with the current business making is an impulse for starting a new business for $7.1 \%$ of start-uppers.

The content of a business idea-data processing (collection, arrangement, and interpretation) is the most typical (36.6\%) business idea, although it has many forms. They are e.g., search engines for goods and various shops, monitoring the movement and delivery of goods, shopping aids, reservation systems, data communication platforms, analytical software, mediation of goods and people, medical documentation, website creation, and more. Furthermore, the content of business ideas is the production and sale of organic products (16.1\%), e.g., garments made of recycled polyester, renewable energy sources, unpackaged sale of drugstore goods, innovative collection of municipal waste, energy-independent housing, energy storage, etc., followed by the sale and partly the manufacturing of a standard product with slight innovation (12.5\%), e.g., sunglasses, street food sales, coffee roaster, Vietnamese bistro, diary, baby box, etc. Health promotion is the essence of $8.9 \%$ of ideas, e.g., elimination of dry eye, 3D anatomy, monitoring of clinical manifestations of the organism, exercise for a healthy back, early and revolutionary cancer diagnosis, genetic service, chair for healthy sitting. This is followed by organic food (8.0\%), e.g., growing fruits and medicinal herbs, production of ready-to-eat food with long shelf-life, special pastries, healthy raw sweets, growing systems, etc. Entertainment and sports contain $7.6 \%$ of ideas, e.g., platform for conducting chess and sports tournaments, social network, conversation platform, plant terrariums, hockey stick tape, e-target, and others. In addition, $5.4 \%$ of ideas are from the field of education and $5.4 \%$ of ideas are used to mediate e.g., programmers, sports grounds, boat rental, etc. Two ideas are from the world of finance.

Causes and circumstances of the origin of a business idea-the circumstances of the idea are somewhat similar to the reasons for the choice of the industry, although they do not pursue the same purpose. Absence of product, unsatisfied need, and demand for missing product account for $34.8 \%$ of causes. The realization of a long-term desire, enthusiasm for a product or business activity makes up $19.6 \%$ of the reasons. The share of random 
stimuli coming from the external environment and previous job (13.4\%) and stimuli that bring environmental awareness and protection, including health promotion $(12.5 \%)$, is not negligible. Inspiration abroad and the transfer of idea home is the cause of $10.7 \%$ of ideas and $5.4 \%$ of ideas arise when they first enter the world of business. In a small number of cases, the causes are personal health problems $(2.7 \%)$ and university graduation $(0.9 \%)$.

Justification for the novelty of the business idea-the exceptional position of a startup in the industry is the most common argument $(42.9 \%)$, which justifies the novelty of a business idea. The uniqueness of the position is manifested as a small number of competitors at home or in Central Europe, absence of competitors, first position in the industry, company establishing an industry, a single company in the industry, in some cases even worldwide, favorable market response/leading position in the industry. The second important justification for novelty is the uniqueness of the product or service (38.4\%). This kind of excellence has very diverse manifestations, e.g., own or original design, novel technology without patent, significant differentiation, complex product, unique product, common knowledge, but interestingly customized, demanding crop cultivation only in rare localities, new food flavors, pure food raw material (not a mixture), healthy food, dried food, different use of the crop for food purposes than the competition, etc. The most objective is the confirmation of novelty by granting a patent $(2.7 \%)$ and filing an application for a patent $(0.9 \%)$. In a small number of cases, start-ups justified novelty with exceptional external support $(2.7 \%)$ from investors and celebrities, the transfer of an exceptional idea from abroad $(2.7 \%)$, and the environmental effects $(1.8 \%)$ of waste-free technology and the environmental traits of products that are reportedly an unknown topic for many consumers. Of note, $8 \%$ of start-ups had an incomplete and unclear justification for originality. The main and generalized new knowledge in Box 1.

Box 1. A. Business idea.

Main and generalized new knowledge

Choice of industry: objective versus subjective relationship of the founder

Content of the business idea: 1. data collection and their structuring, 2. ecology, healthy nutrition and health care

Reasons for the emergence of a business idea: subjective versus objective approach of the founder

Rationale for the originality of the idea: subjective nature

\subsection{Development of Start-Up}

Development of a business idea-most start-ups are in phase $3(29.5 \%)$, in which they sell a more developed product/service, but they generate revenues only to a small extent because the business model is not definitive and there is a high risk of failure. The main problem of this phase is the lack of funds needed for foreign expansion, implementation of sales strategy, procurement of human resources, coverage of operating losses, and investment development. The second, less represented sample are start-ups in phase $2(25.9 \%)$, which started to sell the MVP and achieve the first income. At this stage, the start-ups expect their relations with investors and potential clients to develop. The development is carried out only in small sections due to a lack of finances and investor confidence. Start-ups are constantly making decisions that are high risk. Slightly fewer start-ups $(23.2 \%)$ are in phase 4 , in which the final product is sold, the business model is slightly being modified, and constant growth in sales is recorded. These start-ups have stable customers, increase production and sales capacities, and can generate a sufficiently high profit needed for further investment and growth. The problem is the lack of human resources, especially specialists. Almost every fifth start-up (16.9\%) is in phase 1 and has not started its business, because it is still working on product design and finalizing its business model. The main problem of this phase is to harmonize all processes, test market interest, obtain certificates and patents, but also move from prototype to mass production, which will help reduce unit costs and ultimately the selling price. The least represented are 
start-ups $(4.5 \%)$ in phase 5 , which are experiencing strong growth, increasing sales, and expanding into foreign markets.

Start-up funding cycle-most of the examined start-ups (52.7\%) are in phase 1 of the financial cycle and have not obtained any external financing, they only invest their own saved money or income from revenues. The main reason is that they lack a product that they would present to investors, or they still do not have enough money to develop. Some of them already have the product but have failed to gain investor confidence. Every fifth start-up (19.6\%) is in phase 2 , in which it has made small investments, the source of which is crowdfunding, 3F, a bank loan, or is currently applying for or considering applying for investment, but so far without much success. Smaller investments are also financed by business angels. The capital obtained in this way is mostly used to complete the development of the product or for its serial production. Start-ups (16.9\%), which managed to obtain the first major investments or grants, are in phase 3, acquiring quality specialists, expanding abroad, and attracting the attention of foreign investors. Start-ups $(9.8 \%)$, which have successfully joined investment schemes and made further larger investments, are in phase 4, continue to expand much faster and launch associated services or new products. Only a small number of start-ups $(0.9 \%)$ are in phase 5 , in which they were able to obtain investment funds from large investors. The main and generalized new knowledge in Box 2.

Box 2. B. Start-up development.

Main and generalized new knowledge

Idea development: seemingly perfect solution $\rightarrow$ imperfect business model $\rightarrow$ entry into foreign markets

Financing: the hesitation between independence and external capital

\subsection{Business Model}

\subsubsection{Customer Value Proposition}

Satisfied needs solved customer problems - customers lack data and information the most (25.9\%); they need more specific structured data and information, better access to data and information, and digitized processes. Unusual or better satisfaction of a traditional need $(20.5 \%)$ manifests itself as an interest in uniqueness, authenticity, quality/functionality, non-standard, sophistication, simplification, speed, availability, convenience, comprehensiveness, efficiency, time and cost savings, and more. Maintaining good health (12.5\%) means healthy eating, a healthy lifestyle, organic food, measuring vital signs, and diagnosis. Ecological needs (12.5\%) satisfy the traditional need, but ecologically flawlessly, e.g., organic clothing and housing. Missing resources (12.5\%) in business and civic life are satisfied e.g., by support in setting up e-shops, supplying quality staff, developing a strategy and its presentation, supporting personal growth, renting yachts, doing housework, etc. Mental needs $(7.1 \%)$ are satisfied by the aesthetic experience, entertainment, and education. Eating needs $(7.1 \%)$ respond to the deficit of fast and tasty food, the absence of home-cooked meals, catering, and the unavailability of some foods. A small part of needs $(1.8 \%)$ relates to safety, e.g., reliable investment or personal risk.

Value/usefulness provided to customers-structured data and information have the largest share in the provided values/usefulness (25.0\%), e.g., access to structured data, knowledge, monitoring the course of events, saving time with the information made available, simplification of activities due to available information, more information of its kind, more knowledge. Mental relaxation (16.1\%) and support of physical health $(9.8 \%)$, including a healthy environment $(8.0 \%)$ are values that contribute to improving the functioning of the human body and a healthier feeling of life. Food and its experiential $(7.1 \%)$ and health effects (3.6\%) are also beneficial for the human body. A personal and business presentation, aesthetic experience, sports performance, safe investment and allin-one design (multiple values/benefits together) have marginal values with small shares. Professional assistance in business making (8.9\%) is exclusively focused on meeting the needs of entrepreneurs and companies. 
Minimum viable product-the bearer of value/benefit is mainly a software and image product $(43.8 \%)$, e.g., application, website, platform, analytical and interpretation software, data storage, database, SaaS, $\mathrm{H}+\mathrm{W}+$ blockchain, online transmission of PC games, online video, brokerage portal, etc. It is followed by an item or service of personal consumption $(22.3 \%)$, e.g., drinking straw, toothbrush, special chair, hockey stick tape, controlled garden, plant terrarium, boat rental, party game, charger, e-target. Raw or processed food contributes to the examined values of $9.9 \%$, e.g., raw crop/fruit, processed crop, ready meal, dried food, food delivered, coffee, bistro meal. Different types of knowhow $(9.9 \%)$ are e.g., consultations, advice, education, certified service, diagnostic test, training. The item of wider social consumption is the bearer of value in $8.0 \%$ of cases, for example, playground, machine, chipped garbage containers, electricity storage, etc. Clothing and clothing accessories, e.g., wearing apparel, decoration, sunglasses have a share of $4.5 \%$, and financial products, e.g., deposit account, the investment strategy for individuals have a share of $1.8 \%$.

Verification of conformity of the product with the needs of the market-although startups can determine the percentage of so-called product/market fit, up to $84 \%$ of them cannot confirm this consistency. Approximately $8 \%$ of start-ups say they know the match between their product and market needs based on customer requirements and satisfaction, market research, analysis of potential customer needs, discussions with experts, participation in various conferences, and monitoring trends. In addition, $5.4 \%$ of start-ups rely on their own estimates and assumptions. In three cases, start-ups refer to growing demand, registration on their website, and customization.

\subsubsection{Customer Segments}

Customers-approximately $57.1 \%$ of customers come from the general public and $31.3 \%$ of customers are companies. Young people constitute $9.8 \%$ of customers. A special group consists of programmers and IT specialists (6.3\%) and e-commerce owners (6.3\%) who have experience with IT technologies and relevant education.

Market potential-about $37.5 \%$ of start-ups do not know the potential size of their market, mainly because they go from the domestic market to foreign markets. Further, $19.6 \%$ of start-ups see market potential up to 100 thousand $€, 16.1 \%$ of start-ups up to 1 mils $€, 7.1 \%$ see potential up to 100 mils $€, 8.0 \%$ of start-ups up to 10 mils $€$ and $8.0 \%$ to more than 1 billion $€$. The $2.7 \%$ of start-ups determine the market potential up to 1 billion $€$.

Scaling options-the $42.9 \%$ of start-ups sell their products and services more in large cities, where the purchasing power of the population is higher. Almost a third (31.3\%) of start-ups operate in foreign markets, where room for growth is expected. The $22.3 \%$ of start-ups see room for growth on social networks, which hide considerable growth potential. This is being strengthened by the current coronavirus situation, during which a large part of customers moved from real to virtual space.

\subsubsection{Customer Relations}

Attracting, retaining, and increasing the number of customers-about $41.1 \%$ of startups are present on social networks (Facebook or Instagram). These start-ups are convinced that this is one of the most effective ways to retain a customer and provide quality services not only at the beginning of the business making but also in the next stages of its development. Almost 40\% (39.29\%) of start-ups attract customers with personal assistance, professional recommendations, and reputation. Customers pay attention to the staff and their personal communication if they act in a friendly and professional manner. In addition, $32.14 \%$ of start-ups attract customers with advertising, marketing, and positive references. Communication with customers is important because customers give incentives to change the product/service and expect to adapt to their needs. Lastly, $31.3 \%$ of start-ups emphasize the quality of the offered product or service and $18.8 \%$ of start-ups have no idea how to work with customers. 


\subsubsection{Distribution Channel}

Main distribution channel-about $63.4 \%$ of start-ups contact customers through an online channel that is fast, easily accessible, and integrated with customer behavior. Almost a third (32.1\%) of start-ups communicate with customers directly in their own stores. The customer can personally advise on the selection of the product with trained staff. However, $19.6 \%$ of start-ups could not target the right groups of customers and $17.9 \%$ of start-ups believe that their distribution channel is fully operational and does not need to be improved and streamlined. Almost $10 \%(9.8 \%)$ of start-ups consider it a great challenge and advantage to form new partnerships in the future, gain new contacts, and reach new target groups. Only one start-up $(0.9 \%)$ did not comment on the operation of its distribution channel.

Entry into the foreign market and its advantages and disadvantages-most start-ups $(63.4 \%)$ enter the foreign market through direct exports. They consider the immediate experience with customers, discovering new business opportunities, control over the entire business operation, fast and smooth communication, sales growth, cost reduction, and risks like the advantages of this form of entry. They consider the disadvantages of higher costs of building distribution, ignorance of local conditions, legislation, expectations of the local customer, overcoming the language barrier, higher capital and labor intensity, and a lengthy entry process. About $16.7 \%$ of start-ups entered the foreign market in the form of indirect exports. The advantages of this form of entry are increased sales, reduced costs and risks, and the offer of new business opportunities. The disadvantages are higher costs, adaptation to new legislation, a partial loss of control over the business operation, and loss of interest in finding new markets. In addition, $11.61 \%$ of start-ups entered the foreign market through the sale of a license. The advantages are new, unexpected business opportunities and easy scaling. The disadvantages are lower profits. The construction of the franchising network was chosen by $8.0 \%$ of start-ups who considered the advantage of this form to be business opportunities that would be inaccessible by other forms of entry, sales growth, reduction of distribution costs, the relative simplicity of the entire business operation. They considered the overcoming of legislative barriers, lengthy entry into foreign markets, a loss of control over the business operation, and the risk of incorrect use of know-how to be disadvantages. Only one start-up entered the foreign market through its own sales and thus ended its business (exit strategy).

Other distribution channels (the second option after the main channel)—almost $40 \%$ (38.4\%) of start-ups sell their products mainly through the online channel (e-shop, Twitter, Facebook, Instagram); $36.6 \%$ of start-ups sell directly in a kiosk or their own store; $24.1 \%$ of start-ups have no other distribution channels; $8 \%$ of start-ups sell their own products and services indirectly as part of other products and services; and $4.5 \%$ of start-ups also process orders by phone, because it is inexpensive.

\subsubsection{Key Resources}

Key resources and offered value-most start-ups (72.3\%) consider knowledge, knowhow, and technology, which are necessary conditions for doing business in their industries, to be key sources. The use of these key resources is not possible without human resources and their expertise, which is emphasized by $60.7 \%$ of start-ups. In addition, $41.0 \%$ of start-ups emphasize financial resources; $9 \%$ of start-ups consider quality raw materials and materials to be key sources; and $7.1 \%$ of start-ups do not emphasize a specific resource and its use because they prefer a balanced and harmonized composition of resources. One start-up $(0.9 \%)$ considered its location and position to be a valuable resource.

Lack of resources-most start-ups lack cash (48.2\%) and therefore are looking for investors. A third of start-ups (33\%) emphasize the lack of persistent workers who are willing to improve. A significant problem for $19.6 \%$ of start-ups is the lack of know-how, experience in the chosen business and with the selected technology. Further, $13.4 \%$ of start-ups do not lack any resources and there is enough of everything in their business; $9.8 \%$ of start-ups have the desire and drive for quality and successful business making but 
they lack venues; $6.3 \%$ of start-ups believe that their success depends on marketing and advertising; and $5.4 \%$ of start-ups do not deal with the absence of resources.

\subsubsection{Key Activities}

Key activities and offered value - the key activities are those without which the startup would not be able to create a product or service. These are processes that cannot be outsourced because they form the core of the idea. Start-ups mostly focus on one or two activities. Most start-ups (50.0\%) communicate with customers, market, and sell their products. They also call it market education because they inform potential customers about the problem and explain its solution. In this way, they build a relationship with them, which will sooner or later ensure sales. More than a third of start-ups $(35.7 \%)$ carry out product development themselves. They are programing software, developing unique computer codes that bring a competitive advantage, investing in UX to make the solution convenient for the customer, and constantly testing it. Slightly fewer start-ups (28.6\%) are dedicated to manufacturing a product or providing a service. However, most startups outsource production or use platforms to provide the service, e.g., Android or iOS. Secondary processes are carried out by every tenth start-up (13.4\%). These are logistics, accounting, employee training, procurement of raw materials, etc. Company managing is perceived by few start-ups (6.3\%) as a key process, as well as attracting investors (6.3\%). Very few start-ups do not have defined key activities (1.8\%).

Missing activities-almost one-third of start-ups (28.6\%) do not have ensured sales and promotion. The main reason is the unfinished product, lack of financial resources, and capacity for a larger advertising campaign. Every fourth start-up (25.9\%) lacks no processes. Some start-ups have still not been able to start the production and operational implementation of the idea (14.3\%). They do not have the necessary technology, equipment, premises, permissions, or are just testing. Some start-ups (8.0\%) are still looking for suitable distribution channels. They consider the advantages and disadvantages of allocating distribution while worrying about losing control of the supply process and not ruining a good relationship with customers. Some start-ups $(7.1 \%)$ are still completing the business idea and have not created a MVP. Some start-ups (4.5\%) are missing a part of the business idea. They develop it and add new functionalities according to the needs of clients. Few start-ups $(0.9 \%)$ are still identifying the necessary processes, considering $(0.9 \%)$ establishing the first contact with the market, or they lack $(0.9 \%)$ verification of interest in the product.

\subsubsection{Partners}

Key resources provided by partners-the most important source (45.5\%) that start-ups obtain from their partners is finance. They use them to develop and purchase hardware, software, office equipment, and for production. Finance most often comes from business angels or investors. Start-ups rarely look for partners in banks. Start-up partners (37.5\%) help with technological know-how and professional advice. In typical start-up industries, information and technical knowledge are key to success. Corporate alliances (24.1\%) are also used to supply raw materials and components. Mostly these are specialized raw materials and packaging. To a lesser extent (12.5\%), an external sales network is used, which are platforms (Android, iOS), online sales networks (zlavomat.sk, bistro.sk, accessed on 10 July 2021.), or traditional stores of a partner. Almost every tenth start-up (8.0\%) uses marketing space and channels from its partners. Only a few start-ups (3.6\%) use partners for logistics and warehousing.

Key activities provided by the partners-many start-ups (31.3\%) allocate the supply of raw materials and sales logistics. These are key activities for production and sales because without quality material delivered on time, production will not start. In addition, sales also require professionalism and precision. This is directly followed by other services from partners, namely marketing (25\%) and sales (21.4\%). The advantage of allocating these activities is that they are implemented by established marketing and sales networks, and therefore the start-up can quickly enter the global market. Start-ups also use consulting 
(20.5\%) for technology and IT. The founders have an idea, but they do not have enough knowledge and experience. It is faster and easier for them to buy this knowledge or to acquire it through a partnership. Therefore, they sometimes use partners for technological completion of the product $(18.8 \%)$.

Partnerships-for many start-ups (33.0\%), partnerships are a welcome and a necessary tool for sourcing resources and processes, because otherwise, they will not have access to know-how, technologies, raw materials, logistics, and the sales network. These are mostly proven forms of cooperation based on mutual trust and sometimes even friendship. In addition to working time, teams spend private time with suppliers on team building activities. Some start-ups use partnerships and informal meetings for informal self-presentation and product visibility. Start-ups refer to companies that have the same corporate culture and values as the best partners. Partnerships are less attractive for $19.6 \%$ of start-ups, which value a good experience of quality cooperation. Every fourth start-up has a neutral attitude towards cooperation $(24.1 \%)$. These start-ups do not want to establish any type of cooperation or only exceptionally. They will be enough on their own. However, if an interesting offer came up, they would certainly consider it. Some start-ups are still hiding so that they are not visible to customers, suppliers, or other partners. They are working on their product and do not want to be disturbed yet. Only a few $(7.1 \%)$ start-ups have an aversion to partnerships due to bad experiences. Some investors make it clear they want to get rich quickly and this creates distrust. In one case, the delivery from the partner was of poor quality and delivered late. Few start-ups $(4.5 \%)$ have a higher aversion to partnerships. They fear the misuse of know-how, its disclosure to competitors, the revelation of a complex business model, work procedures, or recipes. The reason for the aversion is also the impatience of the investor, who expects the quick completion of the final product, sales, revenue, and profit.

\subsubsection{Cost Structure}

The largest share of the start-up costs is personnel costs (more than $50 \%$ ), which are spent on employees' wages, especially on the wages of highly qualified employees. The costliest activities are product development (29\%), advertising, promotion (20\%), and sales. With regards to the achieved market prices, $57.0 \%$ of start-ups reach the average level, in the middle between very high and very low; low costs reach $7.9 \%$ and very low costs $3.5 \%$ of start-ups. Compared to the relevant competitors, $45.6 \%$ of start-ups have approximately the same costs, $14.8 \%$ have slightly lower costs and $11.4 \%$ much lower costs. Fixed costs over variable prevail in $28.1 \%$ of start-ups; they are balanced in $30.7 \%$ of start-ups, and variable costs over fixed prevail in $30.3 \%$ of start-ups, while the rest have more significant deviations. The cost structure was stabilized at $60.2 \%$ during the research period, although it will change in the future.

\subsubsection{Revenue Flow}

Customers pay for better, greater satisfaction of the original need or more benefits (56.2\%) for satisfying a completely new need or a new benefit $(24.1 \%)$, for the same but more accessible, prompt or faster satisfaction of the original need $(16,1 \%)$ and the same, but cheaper satisfaction of the original need, or cost savings $(3.6 \%)$. Satisfaction of the needs for which customers pay is bringing practical benefits to the customer, satisfaction of material or mental needs e.g., finding the required information or feeding $(57.1 \%)$, comfort $(15.2 \%)$, entertainment $(8.9 \%)$, keeping up good health $(8.0 \%)$, and other benefits. Sources of income are the sale of a product $(43.8 \%)$, the sale of service $(17.9 \%)$, the mediation of the sale of service $(10.7 \%)$, the sale of a license $(10.7 \%)$, and others. About $6.3 \%$ of start-ups have a freemium model and generate revenue from advertising or for a premium service. The average start-up has approximately 300 users, 70 paying customers and covers $60 \%$ of costs with its revenues. The main and generalized new knowledge in Box 3. 
Box 3. C. Business model.

Main and generalized new knowledge

1. Value offered: everyday needs of an individual customer, little sophisticated MVP, unclear product/market fit

2. Customers: general public, unclear knowledge of market potential, scaling —solvent customers in large cities, in foreign markets and in the online environment

3. Customer relations: social networks

4. Distribution channels: online and direct export to foreign markets

5. Key resources: knowledge/know-how, technology and human resources

6. Key activities: communication with customers, product development and production or service provision

7. Partners: delivering resources-investors, professional advisers and material suppliers and activities-logistics, promotion, sales and development of a business idea

8. Cost structure: the largest share-personnel costs

9. Revenue flows: traditional income models

\subsubsection{Summarizing Experiences/Results}

Positives-almost half of start-ups (46.4\%) considered it a positive and important decision to choose the right novel product/service that succeeds with customers, opens a new market (ideally the blue ocean), and is constantly innovating. They found a gap in the market and filled it with the uniqueness of its kind. Other start-ups (21.4\%) highlighted awards, prizes in contests, participation in a major global event, and the interest of the media, which brought them new business relationships and business contracts. About $14.3 \%$ of start-ups positively evaluated the recruitment of suitable people to the team and finding a partner who accelerated growth. Every tenth start-up (8.0\%) achieved favorable results thanks to marketing, social networks, and promotion, which enabled expansion abroad. Only some start-ups (4.5\%) grew as a result of raising funds, for example through crowdfunding.

Negatives-more than half of start-ups (53.6\%) emphasize that their failure is mainly due to ineffective marketing, which weakens the impact on customers. The second serious problem is the lack of ambitious and trained staff in $23.2 \%$ of start-ups. About $18.8 \%$ of startups have problems with finances, which are necessary for running a business, and $12.5 \%$ of start-ups have problems with suppliers. There were start-ups in the researched sample (7.1\%) which work without problems and do not see shortcomings, failures, or mistakes.

Pivots-pivots are usually fundamental changes in the development of a start-up. However, $30.4 \%$ of start-ups did not make any changes of this kind. A quarter $(25 \%)$ of start-ups changed or developed their business concept, e.g., from hardware to software, from $\mathrm{B} 2 \mathrm{C}$ to $\mathrm{B} 2 \mathrm{~B}$ and vice versa, from product development to product sales, changing the purpose of genetic analysis, integration with another start-up, expanding the purpose of the application to evaluate services, new e-sales technology, change of location and purchase of more powerful technology, from the sale of an individual product to a comprehensive sales and exhibition concept, from a small greenhouse to a microclimate controller and others. In addition, $16.1 \%$ of start-ups made changes in distribution, e.g., another distribution channel, entry into foreign markets, orientation to international markets, expansion of the circle of customers, cooperation with a large business partner, acquisition of a celebrity to support sales, and others. Meanwhile $8.9 \%$ of start-ups considered the acquisition of an investment, the entry of a foreign investor but also the rejection of an investor due to a small investment to be a significant change. The product range was expanded by $6.3 \%$ of start-ups. The rest of the start-ups (5.4\%) changed their internal operations, e.g., improved entrepreneurial abilities and skills, beame a mature company, and therefore focused on organizational guidelines, extreme growth, transition to large-scale production, etc. The main and generalized new knowledge in Box 4. 
Box 4. D. Summary experiences/results.

Main and generalized new knowledge

Positives: finding an unresolved problem and developing a unique product/service

Negatives: poor marketing, lack of quality staff, lack of finances

Pivots: rare and unconceptual

\section{Discussion}

\subsection{Business Idea}

Choice of industry - the reasons for entering a particular industry are personal and subjective, e.g., positive attitude towards the industry, knowledge, experience, and education related to the industry $(44.6 \%)$ or impersonal and objective, e.g., the existence of an unmet need, the attractiveness of the industry, low entry barriers into the industry and the relatedness of the industry (55.4\%). Personal reasons are marked by a desire for selfrealization, high aspirations, perhaps also emotions, objective reasons are accompanied by analysis, insightful observation, and a cold business calculation, which slightly outweighs the pleasure in business making.

Content of a business idea-in summary, ideas dominate, the purpose of which is to collect data and transform it into structured, clear, and easily interpreted information (36.6\%). The second large group consists of ideas that combine ecology, healthy nutrition, and health care $(33.0 \%)$, which improve the quality of human life. There are few ideas that would develop and apply the results of cutting-edge scientific research or come up with groundbreaking innovations. Most of the ideas are based on lower-level product innovations and lack more noticeable business innovations. Compared to developed countries, ideas based on fintech are almost absent. The content of ideas is most influenced by technological and social trends and lifestyles, hence ICT, ecology, organic food, and at the same time the investment simplicity of products and services. An entirely unique idea is extremely rare, most ideas are modifications or improvements of existing business ideas.

Causes and circumstances of the nascence of a business idea-in contrast to the choice of industry, motives that are directly linked to the person of the entrepreneur (65.2\%) predominate over objective reasons $(34.8 \%)$, which are more the result of analyses than informal observation and individual interest. The personal and impersonal elements play a different role in the choice of the industry, which is a space for the implementation of the business idea, and in the reasons for the nascence of the idea itself, which shape its specific content.

Justification of the novelty of the business idea-the arguments in support of novelty are highly subjective. Their source is experience and observation, which are limited by the person of the start-up founder and the territorial size of the market. Most sources of novelty are fragile, their rarity is only local or regional, and in contact with international competition, it will be difficult to defend against imitation. The inability or impossibility to protect novelty, which is perceived as a position in the industry and the uniqueness of the product, is a herald of a start-up's failure. Almost the only way to protect the novelty of the researched start-ups on an international scale is constant innovation and rapid to exponential growth of the company.

\subsection{Start-Up Development}

Development of a business idea-from the observation of start-ups, it can be stated that against the background of five formal phases, they overcome three key stages. The first is the state in which the founder notices the problem and creates a seemingly perfect solution, which, however, changes many times later. At this stage, everything is spontaneous in the start-up, e.g., processes, finance, human resources. In the second stage, a more or less organized business model is created, the minimum viable product is tested, the team of people is stable, the terms of investors and their contributions are clearly defined, and the first sales are generated, in some cases even a small profit. In the third stage, entry into foreign markets takes place, high growth occurs, and above-average profits are achieved. 
Start-up financing cycle-most of the examined start-ups make business only with their own resources or with a very small share of external capital. They strive for independence, do not provide an opportunity for venture capital, and protect themselves from outside influence. They invest earned money, do not pay rewards themselves, and live modestly. However, such growth and development of the company are protracted. Concerns about the imitation of the idea and competition will eventually force start-ups to open their companies to external investors. However, due to hesitation, they lose their competitive advantage. The transformation of a truly original idea into a product and its market expansion without external capital is in principle impossible. The low share of venture capital in the financing of the examined start-ups signals a provincial/parochial business culture and a preference for independence even at the cost of slow growth, with all the negative consequences to the company's perspective.

\subsection{Business Model}

\subsubsection{Customer Value Proposition}

Satisfied needs solved customer problems-typical personal needs (health, ecology, mental, diet, safety) account for $41.0 \%$ of satisfied needs. The remaining $59.0 \%$ of needs are related to personal and business consumption. Thus, satisfying the needs of the individual customer outweighs the needs of the corporate customer. There are not emerging cases of satisfying completely new needs. Unusual needs do not have the nature of revolutionary or completely new needs.

Customer value proposition - the offered values are dominantly oriented to the individual customer and satisfy his needs through a modern and healthy lifestyle. About one-third of the offered values satisfy the needs of the corporate customer through variously structured data and information. Customers experience improvement in business processes, health, or mental relaxation. It is the improvement of existing practice that is the key contribution of start-ups to satisfying customer needs.

Minimally viable product-start-ups create a minimally viable product (MVP) to test a business idea. Most MVPs are seemingly complicated software and image products, but on closer inspection, it is clear that they are based on available and known technologies to the professional public. The MVP in the shape of a thing or personal consumption service is a simple, minimalist product with a low degree of sophistication. Less sophistication or minimalism is influenced not only by the low complexity of the product but also by the effort to eliminate high fixed costs for the implementation of the MVP. Start-uppers prefer a simpler and cheaper product to a more complex and expensive product. It is questionable whether the satisfaction of the domestic customer will withstand even before the confrontation on the European and world market.

Verification of the congruence of the product with the needs of the market-the mismatch between the product and the market is a serious and frequent cause of startup failures. Obviously, confirming this congruence is time- and money-consuming, but ignoring it, underestimating it, or neglecting it makes business an adventure with a very vague result. It is clear from the research that start-ups do not seek to achieve such a match. It is a key success factor, but start-uppers overlook it, they see something brilliant in their idea and rely on feedback only from their immediate surroundings and do not analyze the real market. In addition to the excessive self-confidence of start-uppers, the reason for this attitude is also cost and time savings. The result of ignorance and saving in the wrong place is often a fatal sales failure.

\subsubsection{Customer Segments}

Customers-more than half of start-ups offer their products to the general public, one-third of customers are companies, and the rest of the customers are young people, experts, and users of information technology. The general public and consumers who master information technology are suitable customers for start-ups because they have less bargaining power. The general public is a dispersed and unconcentrated crowd of 
individual customers, and those interested in information technology will probably get something special from a very small company, whose product is at least temporarily unique. The negotiating position of a start-up as a very small company towards corporate customers is significantly weaker.

Market potential-more than one-third of start-ups do not know the size of the market potential. The rest can estimate the market potential, but about $35.0 \%$ of start-ups see market potential only in the range of 100 thousand to 1 million $€$. Once again, there is a simplified view of the present and future of business, which is caused by cautious ambitions or the assumption that later, over time, everything will gradually become clearer. Reluctance, failure to realize the need to spend resources on more extensive market research, or their absence, are not ruled out.

Scaling options-the researched start-ups see room for growth on solvent customers in large cities, in foreign markets, and in the online environment. However, this scaling space can only be considered as the first planned and currently responsive to the corona crisis in the case of virtual space. The second plan of scaling should consider the exhaustion of the first planned scales and the rural customer, distinguish between different solvent foreign markets, and intensification of competition in the online space.

\subsubsection{Customer Relationships}

Attracting, retaining, and increasing the number of customers-the dominant tool for cultivating customer relationships is social networks. Social networks are used to build a brand and constantly promote products and services. This communication is cheap and timesaving. Many start-ups strengthen the relationship with customers through personal contact, which is, however, more expensive and time-consuming. Small start-ups face the dilemma of cultivating a simple and cheap relationship with customers or a more complex and expensive one. However, about one-fifth of start-ups have no idea how to communicate and work with customers. They were able to create a quality product, but they do not know how to get it to the customer and arouse his/her interest.

\subsubsection{Distribution Channel}

Main distribution channel-almost two-thirds of start-ups sell through an online channel because it is cheap and easily accessible without time restrictions. Start-uppers are mostly young people who sell their goods and services, especially to the younger generation, and therefore the online channel is close and natural to both parties. One-third of start-ups use the direct channel to sell complicated or complex products. However, it requires trained and therefore expensive personnel. However, most start-ups use a combination of two channels to increase sales flexibility. About one-quarter of start-ups use only one channel, so they run the risk of failing.

Entering foreign markets-the dominant form of entering the foreign market is direct export, which takes place mostly through e-platforms or language mutations of start-up websites. The whole process of direct export is under control, it can be immediately evaluated and changed. Online sales enable interactive communication with customers and quick modification of the product according to customer needs. Direct exports predominate because start-ups do not like to relinquish control of their business and want to be independent in business operations as well.

\subsubsection{Key Resources}

Key resources-the key resources of start-ups are knowledge/know-how, technology, and human resources. This trio is the essence of the start-up and the basis of competitive advantage. In addition, another key source is finance that a start-up can obtain from external investors. Finance becomes a source of competitive advantage not only in terms of its size but also in its ability to procure it. Obviously, this capability also depends on the trio of key sources. A minimum number of start-ups place emphasis on raw materials, 
materials, location, and position. The reason is the limited possibilities of a small start-up and making business mainly in the online world.

Missing resources-start-ups lack resources that are important, but in reverse order; it is cash, tough workers, and know-how. In such a situation, investors tend to claim that money for quality ideas and projects will always be found. The problem is businessattractive ideas and their convincing feasibility.

\subsubsection{Key Activities}

Key activities-the researched start-ups consider communication with customers, product development, and product manufacturing or service provision to be key processes. They try to know and understand the needs of the target customer, and then develop and manufacture the product that the customer buys. Most start-ups outsource other primary and support processes for partners. However, the analysis shows that a considerable proportion of the identified key activities are also allocated to partners, in particular, product development and manufacturing. The founders have a very limited work capacity; it is complicated and difficult for them to compile and carry out a more coherent chain of processes, and therefore they have to choose the right very narrow range of processes only.

Missing activities-some start-ups do not sell and promote and do not have a distribution channel, the MVP. The reasons are various, e.g., lack of finances, unfinished product, failure of business idea, misunderstanding of the needs of the target customer. However, there are also start-ups that claim to have all the processes, but the degree of their development is low, and the future will only show the need for further processes.

\subsubsection{Partners}

Key resources provided by partners- the most important partners are investors, professional advisers, and material suppliers. Thus, start-ups miss most finances for the operation of the company, technological know-how, and special materials because they cannot secure them internally or it is advantageous to procure externally. Decision-making depends on the need to maintain independence or to procure the necessary resources effectively.

Key activities performed by the partners-the most important are the partners who perform supply and sales logistics, promotion, sales, and development of the business idea. These are activities that exceed the capacity, expertise, and experience of the start-up team; some of them are needed irregularly and others will help speed up and improve the development of a business idea. Start-ups can thus focus on their primary activities, which are the identification of needs of customers and product development.

Partnerships-start-ups are very vulnerable when choosing partners because financial and time losses are usually irreversible in the case of poor selection. Cooperation with a non-professional partner can be liquidating. On the other hand, working with a responsible and reliable partner can result in a long-term mutually beneficial relationship.

\subsubsection{Cost Structure}

Start-ups have a slightly lower level of costs compared to the relevant competitors than to the market prices. However, this positive competitive difference cannot, perhaps yet, be reflected in higher prices. Personnel costs have the largest share in the cost structure because start-ups usually employ expensive specialists. The lower level of costs compared to the competition is probably due to more efficient technology and the inability to achieve higher prices is probably related to the less bargaining power of a small and nascent, unknown company.

\subsubsection{Revenue Flows}

The researched start-ups did not come up with exceptional business models and instead focused on traditional income models. Customers are especially willing to pay for satisfying traditional needs that are satisfied better, faster, more comfortably, or cheaper. The customer value proposition, which satisfies the needs, is mostly of a practical nature, 
its bearer is mainly the product and the service. Some exceptional business models are set up so that the source of income is not customers, but a third party that benefits from a large number of active users.

A summary view of the business models of the examined start-ups is expressed in Table 1. In the blocks of the business model compiled according to the visualization of the Canvas, the items are listed in order according to their share in the research sample. From the display, it is possible to judge which items are preferred, or what start-ups emphasize, or what they focus on against a background of very limited financial, human and technical resources. Start-ups necessarily have to pursue a stricter and narrower choice of very limited options compared to larger and older companies.

Table 1. A summary view of the business model of the examined start-ups.

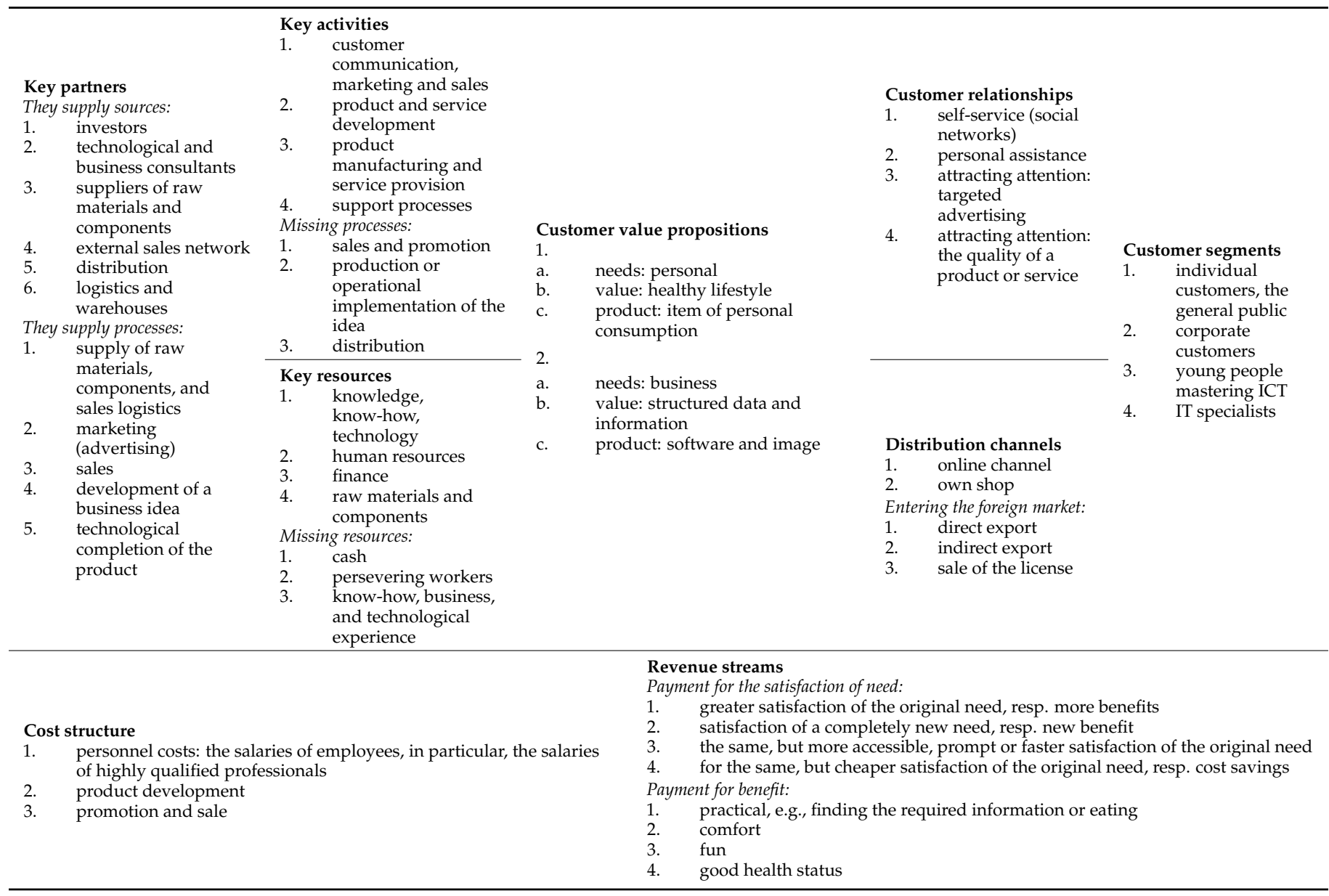

The attributes and content of the start-up business model are influenced by extremely limited resources. The only source is a business idea de facto. Limited resources restrict all blocks of the business model, the development and operation of which must be addressed through partners who provide the missing resources, processes, customer relationships, and distribution channels. Start-ups usually retain only the development of the business idea, product development, and market testing, procure most of the other activities and components of the model from partners, and then coordinate external resources and processes. The division of resources and processes between the start-up and partners depends on the following: the work capacity of the start-up, which is usually very small; on the effort to maintain independence from partners, especially investors entering the equity; on the efficiency and ability to perform processes; on the distance between a start-up and a customer; on the simplicity or complexity of entering the distribution channels; and on the quality and complementarity of resources. Research has shown that partners are often 
needed who provide special know-how to complete a business idea and entrepreneurial skills, experience, and contacts. The space for variations of the business model of start-ups with the definition of boundaries is shown in Table 2, but it follows from the nature of the start-up that the model will almost always be significantly minimalistic, and the variations will not occupy the entire range offered.

Table 2. Space for variations of the business model of start-ups.

\begin{tabular}{|c|c|c|c|c|}
\hline $\begin{array}{l}\text { Key partners } \\
\text { maximum partners } \\
\text { (start-up = business } \\
\text { idea and product } \\
\text { development) }\end{array}$ & $\begin{array}{l}\text { Key activities } \\
\text { minimum } \\
\text { (independence) } \\
t \\
\text { maximum } \\
\text { (dependence) }\end{array}$ & $\begin{array}{l}\text { Customer value propositions } \\
\text { a completely new need } \\
\text { a completely new valuea } \\
\text { completely new product }\end{array}$ & $\begin{array}{l}\text { Customer relationships } \\
\text { self-service } \\
\pm \\
\text { co-creation }\end{array}$ & $\begin{array}{l}\text { Customer segments } \\
\text { mass, non-segmented } \\
\text { market } \\
\square\end{array}$ \\
\hline $\begin{array}{l}\downarrow \\
\text { (start-up = almost all } \\
\text { resources and } \\
\text { processes)minimum } \\
\text { partners }\end{array}$ & $\begin{array}{l}\text { Key resources } \\
\text { minimum } \\
\text { (independence) } \\
\begin{array}{l} \\
\text { maximum } \\
\text { (dependence) }\end{array}\end{array}$ & $\begin{array}{l}\downarrow \\
\text { original need } \\
\text { more quality value/lower costs } \\
\text { more or less improved product }\end{array}$ & $\begin{array}{l}\text { Distribution channels } \\
\text { one channel } \\
\downarrow \\
\text { several channels } \\
\text { main channel } \\
\downarrow \\
\text { supplementary channels }\end{array}$ & $\begin{array}{l}\text { customization } \\
\text { individual customer } \\
\square \\
\text { corporate customer }\end{array}$ \\
\hline
\end{tabular}

\section{Cost structure}

Fixed versus variable costs: very high fixed costs

I

very high variable costs

Costs in relation to the achieved prices: very high

\section{$\pm$}

very low

Costs compared to relevant competitors:

much higher

\section{I}

much lower

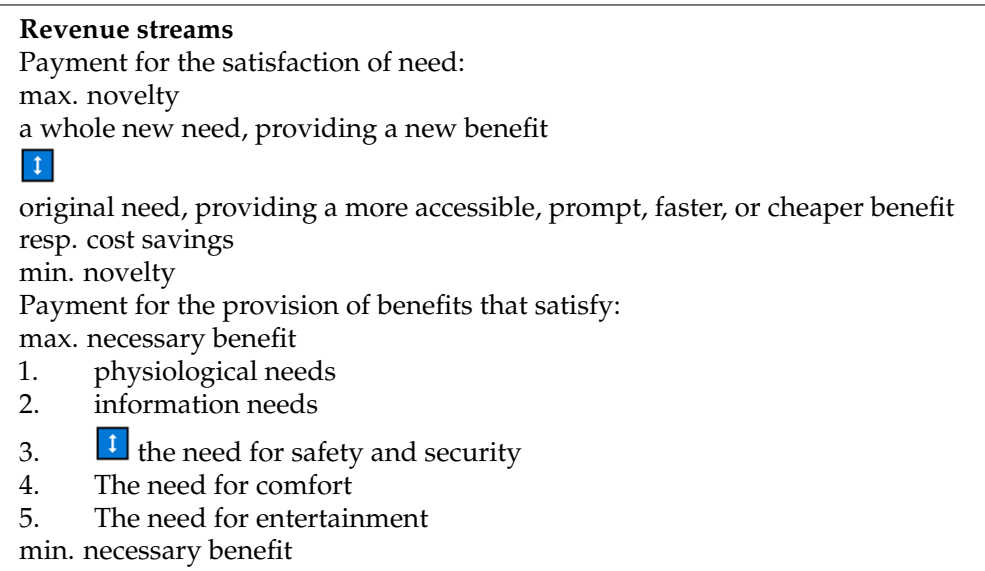

\subsection{Summary Evaluation}

Positives-Start-ups found an unresolved issue and developed a unique product/ service that set them apart from competitors and is a potential source of high profit. They have been placed at the forefront of international contests, raising their profile in foreign markets, attracting high-quality people, finding a useful partner, and creating a strong brand and product awareness. Positives are largely a prerequisite or promise of possible future success.

Negatives-Weaknesses of the examined start-ups were poor-quality marketing, which means mainly expensive and ineffective advertising, lack of trained and ambitious staff, irregular financing of the normal operation of the company, and unreliable suppliers. Employees quickly lost enthusiasm and passion, irresponsible suppliers slowed the progress of the start-up, missing funds almost stopped business processes, and ineffective advertising consumed resources and did not deliver the desired results.

Pivots-The researched start-ups pivot little and part of the pivots is a consequence of the natural development and growth of the company. Conceptual changes are made by only a quarter of start-ups, and usually only one major change in the entire period of its existence. Experimenting with a business idea should be a common and regular part of start-up development [71], as it is a very small and flexible company with very few resources, and therefore pivots should not result in destroyed or unnecessarily spent resources, except perhaps time and wages. The researched start-ups devoted too long 
to one idea without verifying its viability on the market, which is also confirmed by the absence of a credibly verified match between the product and the market.

There are few general conclusions for other companies. The biggest potential of high profit lies in developing of a new product or service. Weak and ineffective marketing, lack of trained and ambitious staff and unreliable suppliers destruct companies. Changing business ideas, experimenting and conceptional changes increase the likelihood of making a higher profit.

The founders of start-ups face several challenges. Start-ups should have a better understanding of markets and customer needs, as they are too obsessed with the seeming uniqueness of their product only, and thus do not perceive real market interest in the solution offered and real market potential. This is partly substituted by crowdfunding platforms, but not every founder wants to finance product development in this way. The second challenge is the credible confirmation of the novelty of the idea and the impact of novelty on the market potential. However, the most important challenge for start-up business making and its research remains a resilient, functioning, and efficient business model, including pricing, which is put into practice by a well-thought-out business strategy.

The researched start-ups did not use open innovations, as they are too closed and protect their supposed strengths and ideas. Space for their application would be found in the canvas diagram (Table 2. Space for variations of the business model of start-ups), which shows the ranges of variability of the business model.

Realized research on business models of start-ups hardly finds comparable studies. Marvin et al. [72] examined business models of circular start-ups, but they did not deal with the internal structure based on canvas visualization. The result of their research was the division of business models into typological groups, so there was no penetration and opportunity to compare with the presented research. Ranniko et al. [73] dealt with the survival of new technology-based firms, but they noted rather well-visible factors, e.g., insufficient will to grow, creation of new jobs, survival and growth rates, but did not deeply identify the causes of these external manifestations of viability. Balboni et al. [74] examined the development of business models, their efficiency and innovation, but the structure of their research object was different than in the presented research.

\section{Conclusions}

The business idea is created against the background of the industry. When choosing an industry, impersonal, analytical reasons slightly prevail over personal ones. In the creation of the business idea itself, personal causes significantly outweigh objective, analytical ones. Start-up founders enter the business because they want to realize their avocations and dreams, or they notice a gap in the market. In particular, the market lacks structured data and tools for their analysis, organic products, and healthcare. However, the founders of start-ups do not have reliable evidence of the uniqueness of the product, their justifications are vague and based on impressions, they even have trouble identifying the target customer.

Start-uppers solve three key problems, which are finding an unmet need/suitable product, building a functioning and effective business model, and obtaining external finance for the rapid development of the product and model. Start-ups mainly satisfy the needs of the individual customer with simpler products and less satisfy the needs of the corporate customer, but with more sophisticated products. The market for individual customers is massive. The corporate customer market is more customized. A serious problem and a common cause of failure are that start-ups cannot accurately measure product-market fit.

The presence of start-ups on social networks and the cultivation of PR are essential because they allow building a brand cheaply and effectively. The main distribution channel is online sales, which facilitates entry into foreign markets too. The key sources of start-ups are knowledge/know-how/technology, people, and financial resources. The key activities are customer communication, marketing and sales, product and service development, and product manufacturing and service provision. However, sales are a weak point of 
most start-ups. Partnerships are essential for resource- and process-limited start-ups, but founders perceive partners in a wide range of positive-negative attitudes and prefer careful partner choice.

Start-ups achieve a lower level of costs compared to the competition because they have only the necessary resources and processes they need to survive and succeed in business making. The cost structure is dominated by wages and fixed costs prevail over variable costs, and therefore slows down the turnover of invested financial resources.

Start-ups do not take much risk in sales and focus on traditional income models. As a rule, they satisfy existing, traditional practical needs with a better or greener product. Only a fraction of start-ups discovers completely new needs, solve a long-term unresolved problem and develop a world-unique product/service. If such a product is found, the start-up, due to low bargaining power, is unable to translate exceptionality into a high price.

The limitation of research on business models of start-ups consisted mainly in regional localization, which, on the other hand, showed regional peculiarities. These limitations can be overcome in the future by enlarging the research sample and purposefully comparing it with other regions.

The criteria of sustainability of a start-up business are indicators of its performance, e.g., number of users, number of customers, sales and profit. Future research should focus on identifying and verifying determinants that affect performance, e.g., quality of staffing, quality of business idea, structure of business model, choice of company development strategy and choice of business strategy. Entrepreneurs and researchers should focus not only on the factors that are crucial for immediate, short-term success and survival, but also on the factors that are crucial for the long-term sustainability of the business making.

There are few topics for the next research. For start-ups, one of the most important issues is to find some tools for verification of originality and identification of customer. They are looking for ways on how to find the right product for the right customer. If they would have this kind of tool, it would be much easier to build the right and effective business model. There is also a big market to find some start-up solutions for business area. The next research should also aim to measure product-market fit. The last research area should be aimed at studying the sales part of business models and structure and effectiveness of business models.

Author Contributions: Each author (Š.S, R.B. and I.M.H.) has equally contributed to this publication. Conceptualization, Š.S. and R.B.; methodology, Š.S.; software, R.B.; validation, Š.S., R.B. and I.M.H.; formal analysis, I.M.H.; investigation, Š.S. and R.B.; resources, Š.S.; data curation, Š.S. and R.B.; writing—original draft preparation, Š.S., R.B. and I.M.H.; writing—review and editing, R.B.; visualization, I.M.H.; supervision, Š.S.; project administration, I.M.H.; funding acquisition, Š.S. All authors have read and agreed to the published version of the manuscript.

Funding: This article is funded from the VEGA project of the Ministry of Education of the Slovak Republic no. 1/0631/19 "Metamorphoses of start-ups on the road to business success" in the range of $100 \%$.

Institutional Review Board Statement: The study was conducted according to the guidelines of the Declaration of Helsinki.

Informed Consent Statement: Informed consent was obtained from all subjects involved in the study.

Data Availability Statement: The data presented in this study are available on request from the corresponding author.

Acknowledgments: This article is a partial output of the solution of the VEGA project of the Ministry of Education of the Slovak Republic no. 1/0631/19 "Metamorphoses of start-ups on the road to business success" in the range of $100 \%$.

Conflicts of Interest: The authors declare no conflict of interest. 


\section{References}

1. $\quad$ van Winden, W.; Kör, B.; Sierhuis, D.; Grijsbach, P. Tech Scale-Ups in the Amsterdam City Region; Hogeschool van Amsterdam: Amsterdam, The Netherlands, 2020; p. 5.

2. Rydehell, H.; Isaksson, A. Initial configurations and business models in new technology-based firms. J. Bus. Models 2016, 4, 63-83.

3. Voinea, C.L.; Logger, M.; Rauf, F.; Roijakkers, N. Drivers for sustainable business models in start-ups: Multiple case studies. Sustainability 2019, 11, 6884. [CrossRef]

4. Saura, J.R. Using data sciences in digital marketing: Framework, methods, and performance metrics. J. Innov. Knowl. 2021, 6, 92-102. [CrossRef]

5. Economic and Business Aspects of Sustainability. 2020. Available online: https://www.mdpi.com/journal/sustainability/sectio ns/management_aspects_of_sustainability (accessed on 20 June 2021).

6. Saura, J.R.; Ribeiro-Soriano, D.; Palacios-Marqués, D. From user-generated data to data-driven innovation: A research agenda to understand user privacy in digital markets. Int. J. Inf. Manag. 2021. [CrossRef]

7. Kanwal, N.; Awan, U. Role of design thinking and biomimicry in leveraging sustainable innovation. In Industry, Innovation and Infrastructure, Encyclopedia of the UN Sustainable Development Goals; Leal Filho, W., Azul, A.M., Brandli, L., Lange Salvia, A., Wall, T., Eds.; Springer Nature Switzerland AG: Cham, Switzerland, 2020. [CrossRef]

8. Awan, U. Steering for sustainable development goals: A typology of sustainable innovation. In Industry, Innovation and Infrastructure: Encyclopedia of the UN Sustainable Development Goals; Leal Filho, W., Azul, A., Brandli, L., Lange Salvia, A., Wall, T., Eds.; Springer Nature Switzerland AG: Cham, Switzerland, 2020. [CrossRef]

9. Procházková, K. Podnikatel'ské modely vybraných medzinárodne činných podnikov/Business models of internationally acted companies. In Revue Mladých Vedcov; Inštitút Manažmentu, Fakulta Riadenia a Informatiky, Žilinská Univerzita v Ži-line: Žilina, Slovakia, 2014; pp. 70-72, ISBN 978-80-554-0892-7.

10. Kollmann, T.; Stöckmann, C.; Hensellek, S.; Kensbock, J. European Start-Up Monitor. German Start-Ups Association. 2016. Available online: https://duepublico2.uni-due.de/servlets/MCRFileNodeServlet/duepublico_derivate_00043444/ESM_2016 .pdf (accessed on 20 June 2020).

11. Blank, S.; Dorf, B. The Start-Up Owner's Manual: The Step-By-Step Guide for Building a Great Company, 1st ed.; Wiley: Hoboken, NJ, USA, 2020; ISBN 978-1-119-69068-9.

12. Jain, S. Growth of startup ecosystems in India. Int. J. Appl. Res. Stud. 2018, 2, 152-154.

13. Calvino, F.; Criscuolo, C.; Menon, C. Cross-country evidence on start-up dynamics. In OECD Science, Technology and Industry Working Papers; OECD Publishing: Paris, France, 2015. [CrossRef]

14. Vision. European Startup Network. 2021. Available online: https://europeanstartupnetwork.eu/vision/ (accessed on 2 May 2021).

15. European Startup Monitor 2019/2020. 2020. Available online: http://www.europeanstartupmonitor2019.eu/EuropeanStartupM onitor2019_2020_21_02_2020-1.pdf (accessed on 1 April 2021).

16. Tech Startups. How Many Tech Startups Are Created Each Year? 2020. Available online: https://netshop-isp.com.cy/blog/howmany-tech-startups-are-created-each-year/ (accessed on 11 May 2021).

17. Devadiga, N.M. Software engineering education: Converging with the startup industry. In Proceedings of the 2017 IEEE 30 th Conference on Software Engineering Education and Training (CSEE\&T), Savannah, GA, USA, 7-9 November 2017. [CrossRef]

18. Cockayne, D. What is a start-up firm? A methodological and epistemological investigation into research objects in economic geography. Geoforum 2019, 107, 77-87. [CrossRef]

19. Reisdorfer-Leite, B.; de Oliveira, M.M.; Rudek, M.; Szejka, A.L.; Junior, O.C. Start-up Definition Proposal Using Product Lifecycle Management. In Proceedings of the IFIP International Conference on Product Lifecycle Management, Rapperswil, Switzerland, 5-8 July 2020; pp. 426-436.

20. Tripathi, N.; Seppänen, P.; Boominathan, G.; Oivo, M.; Liukkunen, K. Insight into startup ecosystems through exploration of multi-vocal literature. Inf. Softw. Technol. 2019, 104, 56-77. [CrossRef]

21. Dimitropoulos, P.; Koronios, K.; Kriemadis, A. Employees' motivation and performance: Examining the impact of ethical values and emotional intelligence of employees in high-tech startup companies. In Proceedings of the International Conference on Innovation and Entrepreneurship, Kalamata, Greece, 19-20 September 2019. Available online: https://search.proquest.com/op enview / be8021bbddc5050eb7c5bfceb75ba48e/1?pq-origsite=gscholar\&cbl=4451211 (accessed on 20 June 2020).

22. Taulli, T. How to Create the Next Facebook; Springer: New York, NY, USA, 2012; p. 122, ISBN 978-1-4302-4647-3.

23. Kim, W.C.; Mauborgne, R. Blue Ocean Strategy; Harvard Business Review Press: Brighton, MA, USA, 2014; p. 3, ISBN 1625274505.

24. Hessels, J.; Gelderen, M.; Thurik, R. Drivers of entrepreneurial aspirations at the country level: The role of start-up motiva-tions and social security. Int. Entrep. Manag. J. 2008, 4, 401-417. [CrossRef]

25. Wadhwa, V.; Holly, K.; Aggarwal, R.; Salkever, A. Anatomy of an Entrepreneur: Family Background and Motivation. Kauffman Foundation Small Research Projects Research. 2009. Available online: https:// papers.ssrn.com/sol3/papers.cfm?abstract_id=14 31263 (accessed on 11 April 2021).

26. Dessyana, A.; Riyanti, B.P.D. The Psychological Factors That Founder Need to Build and Develop a Digital Start-Up. Global Journal of Management and Business Research. 2019. Available online: https://journalofbusiness.org/index.php/GJMBR/articl e/view/2876 (accessed on 21 May 2021). 
27. Mattsson, L.G.; Anderson, P. Private-public interaction in public service innovation processes-business model challenges for a start-up EdTech firm. J. Bus. Ind. Mark. 2019. [CrossRef]

28. Krishna, H.S.; Subrahmanya, B.M.H. Phases and key challenges in Indian internet startup lifecycle: Transnational entrepreneurship vs. local entrepreneurship. In Technology Transfer and Entrepreneurship; Bentham Science Publishers: Sharjah, United Arab Emirates, 2016; Volume 3, pp. 90-100.

29. Dessyana, A.; Riyanti, B.P.D. The influence of innovation and entrepreneurial self-efficacy to digital startup success. Int. Res. J. Bus. Stud. 2017, 10. [CrossRef]

30. Kropp, F.; Lindsay, N.J.; Shoham, A. Entrepreneurial orientation and international entrepreneurial business venture startup. Int. J. Entrep. Behav. Res. 2008, 14, 102-117. [CrossRef]

31. Carrete, L.S.; Faria, A.M. The financing of the start-up life cycle. In Start-Ups and Innovation Ecosystems in Emerging Markets; Palgrave Macmillan: Cham, Switzerland, 2019; pp. 69-95. [CrossRef]

32. Coleman, S.; Cotei, C.; Farhat, J. The debt-equity financing decisions of U.S. start-up firms. J. Econ. Financ. 2014, 38. [CrossRef]

33. Markova, S.; Petkovska-Mircevska, T. Financing Options for Entrepreneurial Ventures. Economic Interferences. Available online: https:/ / core.ac.uk/download/pdf/6502301.pdf (accessed on 20 June 2020).

34. Deffains-Crapsky, C.; Sudolska, A. Radical innovation and early stage financing gaps: Equity-based crowdfunding challenges. J. Posit. Manag. 2014. [CrossRef]

35. Frid, C.J.; Wyman, D.M.; Gartner, W.B.; Hechavarria, D.H. Low-wealth entrepreneurs and access to external financing. Int. J. Entrep. Behav. Res. 2016, 22, 531-555. [CrossRef]

36. Mäkäräinen-Suni, I. The Eventful Journey from Idea to Business: Opportunity Development and Exploitation Process of a Digital Technology Start-Up. British Academy of Management. 2017. Available online: http://urn.fi/URN:ISBN:978-0-9956413-0-3 (accessed on 11 May 2020).

37. Franke, N.; Lettl, C.; Roiser, S.; Tuertscher, P. Does good play dice? Randomness vs. deterministic explanations of idea origi-nality in crowdsourcing. In Proceedings of the 35th DRUID Celebration Conference 2013, Barcelona, Spain, 17-19 June 2013. Available online: http:/ / www.aakkozzll.com/pdf/ franke.pdf, (accessed on 11 June 2020).

38. McIntosh, T.; Mulhearn, T.J.; Mumford, M.D. Taking the good with the bad: The impact of forecasting timing and valence on idea evaluation and creativity. Psychol. Aesthet. Creat. Arts 2019. [CrossRef]

39. Zhang, S.I. The business model of journalism start-ups in China. Digit. J. 2018, 7, 614-634. [CrossRef]

40. Afuah, A. Business Models: A Strategic Management Approach; McGraw-Hill Companies: New York, NY, USA, 2003.

41. Osterwalder, A.; Pigneur, Y. Business Model Generation; Wiley: Hoboken, NJ, USA, 2010.

42. Eckhardt, J.T. Opportunities in business model research. Strateg. Organ. 2014, 11. [CrossRef]

43. Iwu, C.G. Sustaining small businesses in emerging economies: An examination of the pre and post-start-up ramifications. Probl. Perspect. Manag. 2017, 15, 227-236. [CrossRef]

44. CB Insight. 2018. Available online: https://www.cbinsights.com/research/startup-failure-reasons-top/ (accessed on 15 April 2020).

45. Slávik, Š.; Hagarová, R. Podnikatel'ské modely startupov/Business models of start-ups. In Podnikatel'ské Modely a Podnikatel'ské Stratégie Startupov II; Vydavatel'stvo Ekonóm: Bratislava, Slovakia, 2016; pp. 162-169.

46. Troung, A. After Analyzing 200 Founders' Post Mortems, Researchers Say These Are the Reasons Start-Ups Fail. 2017. Available online: https: / / qz.com/682517/after-analyzing-200-founders-postmortems-researchers-say-these-are-the-reasons-startups-fail/ (accessed on 7 June 2020).

47. Ghezzi, A.; Cavallo, A. Agile business model innovation in digital entrepreneurship: Lean startup approaches. J. Bus. Res. 2020, 110, 519-537. [CrossRef]

48. Felin, T.; Gambardella, A.; Stern, S.; Zenger, T. Lean Startup and the Business Model: Experimentation Revisited. Forthcoming in Long Range Planning. 2019. Available online: https:/ / papers.ssrn.com/sol3/papers.cfm?abstract_id=3427084 (accessed on 20 April 2021).

49. Eisenmann, R.T. Hypothesis-Driven Entrepreneurship: The Lean Startup. In Harvard Business School Entrepreneurial Management Case No. 812-095. 2012. Available online: https:/ / papers.ssrn.com/sol3/papers.cfm?abstract_id=2037237 (accessed on 11 May 2021).

50. Weking, J.; Böttcher, T.P.; Hermes, S.; Hein, A. Does business model matter for startup success? A quantitative analysis. In Proceedings of the 27th European Conference on Information Systems (ECIS), Stockholm and Uppsala, Sweden, 8-14 June 2019.

51. Seggie, S.H.; Soyer, E.; Pauwels, K.H. Combining big data and lean startup methods for business model evolution. AMS Rev. 2017, 7, 154-169. [CrossRef]

52. Hunter, D.S.; Saini, A.; Zaman, T. Picking Winners: A Data-Driven Approach to Evaluating the Quality of Start-Up Compa-nies. 2017. Available online: https:/ / www.semanticscholar.org/paper/Picking-Winners\%3A-A-Data-Driven-Approach-to-the-ofHunter-Saini/faba557313d2fef95ff3ab6319103af6215569f6 (accessed on 20 August 2020).

53. Mor, S. Choice of Small Business in Informal Sector: Case of India. 2018. Available online: https://www.researchgate.net/publi cation/323995436_Choice_of_Small_Business_in_Informal_Sector_Case_of_India (accessed on 5 June 2020).

54. Ghezzi, A.; Cavallaro, A.; Rangone, A.; Balocco, R. A comparative study on the impact of business model design and lean startup approach versus traditional business plan on mobile startups performance. In Proceedings of the 17th International Conference on Enterprise Information Systems, Barcelona, Spain, 27-30 April 2015; pp. 196-203. 
55. Silva, D.S.; Ghezzi, A.; de Aguiar, R.B.; Cortimiglia, M.N.; ten Caten, C.S. Lean startup, agile methodologies and customer development for business model innovation: A systematic review and research agenda. Int. J. Entrep. Behav. Res. 2020, 26. [CrossRef]

56. Filho, W.L.; Azul, A.M.; Brandli, L.; Özuyar, P.G.; Wall, T. Responsible consumption and production. In Earth and Environ-mental Science: Reference Module Physical and Materials Science; Springer: Cham, Switzerland, 2020. [CrossRef]

57. Uttama, N.P. Open innovation and business model of health food industry in Asia. J. Open Innov. Technol. Mark. Complex. 2021, 7, 174. [CrossRef]

58. Yun, J.J.; Zhao, X. Business model innovation through a rectangular compass: From the perspective of open innovation with mechanism design. J. Open Innov. Technol. Mark. Complex. 2020, 6, 131. [CrossRef]

59. Peñarroya-Farell, M.; Miralles, F. Business model dynamics from interaction with open innovation. J. Open Innov. Technol. Mark. Complex. 2021, 7, 81. [CrossRef]

60. Pakura, S. Open innovation as a driver for new organisations: A qualitative analysis of green-tech start-ups'. Int. J. Entrep. Ventur. 2020, 12, 109-142. [CrossRef]

61. Yun, J.J. Business Model Design Compass: Open Innovation Funnel to Schumpeterian New Combination Business Model Developing Circle, 1st ed.; Springer: Berlin, Germany, 2017; p. 34.

62. Nguyen-Duc, A.; Weng, X.; Abrahamsson, P. A preliminary study of agility in business and production-Cases of early-stage hardware startups. In Proceedings of the ACM International Symposium on Empirical Software Engineering and Measure-ment (ESEM), New York, NY, USA, 11-12 October 2018; pp. 1-4. [CrossRef]

63. Ghezzi, A. Digital start-ups and the adoption and implementation of lean start-up approaches: Effectuation, bricolage and opportunity creation in practice. Technol. Forecast. Soc. Chang. 2018. [CrossRef]

64. Tukiainen, T.; Burstrom, T.; Lindell, M. The Strategies of technology startups within and between business ecosystems. Technol. Innov. Manag. Rev. 2019, 9. [CrossRef]

65. Gutbrod, M.; Münch, J.; Tichy, M. How do software startups approach experimentation? Empirical resultsfrom a qualitative interview study. In Product-Focused Software Process Improvement, Proceedings of the PROFES 2017, Innsbruck, Austria, 29 November-1 December 2017; Felderer, M., Méndez Fernández, D., Turhan, B., Kalinowski, M., Sarro, F., Winkler, D., Eds.; Springer International Publishing AG: Cham, Switzerland, 2017; Volume 10611, pp. 297-304. [CrossRef]

66. Linton, G. Innovativeness, risk-taking, and proactiveness in start-ups: A case study and conceptual development. J. Glob. Entrep. Res. 2019, 9, 20. [CrossRef]

67. Hilbig, R.; Etsiwah, B.; Hecht, S. Berlin start-ups-The rise of data-driven business models. In Proceedings of the ISPIM Con-nects Fukuoka-Building on Innovation Tradition, Fukuoka, Japan, 2-5 December 2018.

68. Tiba, S.; van Rijnsoever, F.J.; Hekkert, M.P. Sustainability start-ups and where to find them: Investigating the share of sustainability start-ups across entrepreneurial ecosystems and the causal drivers of differences. J. Clean. Prod. 2021, 306, 127054. [CrossRef]

69. Kuckertz, A.; Breandle, K.; Gaudig, A.; Hinderer, S.; Morales Reyes, C.A.; Prochotta, A.; Steinbrink, K.M.; Berger, E.S.C. Start-ups in times of crisis-A rapid response to the COVID-19 pandemic. J. Bus. Ventur. Insights 2020, 13, e00169. [CrossRef]

70. Franceschelli, M.V.; Santoro, G.; Candelo, E. Business model innovation for sustainability: A food start-up case study. Br. Food J. 2018, 120, 2483-2494. [CrossRef]

71. McDonald, R.; Bremner, R. When it's time to pivot, what's your story? How to sell stakeholders on a new strategy. Harv. Bus. Rev. 2020, 98, 98-105.

72. Marvin, H.; Bauwens, T.; Hekkert, M.; Kirchherr, J. A typology of circular start-ups: An analysis of 128 circular business models. J. Clean. Prod. 2020, 245, 118528.

73. Rannikko, H.; Tornikoski, E.T.; Isaksson, A.; Lofsten, H. Survival and growth patterns among new technology-based firms: Empirical study of cohort 2006 in Sweden. J. Small Bus. Manag. 2019, 57, 640-657. [CrossRef]

74. Balboni, B.; Bortoluzzi, G.; Pugliese, R.; Tracogna, A. Business model evolution, contextual ambidexterity and the growth performance of high-tech start-ups. J. Bus. Res. 2019, 99, 115-124. [CrossRef] 